\title{
Suppression of IgE Production by IPD-1151T (Suplatast Tosilate), a New Dimethylsulfonium Agent: (2) Regulation of Human IgE Response
}

\author{
Yukiyoshi Yanagihara ${ }^{1}$, Mamoru Kiniwa ${ }^{1}$, Koichi Ikizawa ${ }^{1}$, Takao Shida ${ }^{1}$, Naosuke Matsuura ${ }^{2}$ and Akihide Koda ${ }^{2}$ \\ ${ }^{I}$ Clinical Research Center for Allergy, National Sagamihara Hospital, 18-1 Sakuradai, Sagamihara, Kanagawa 228, Japan \\ ${ }^{2}$ Department of Pharmacology, Gifu Pharmaceutical University, Mitahora-higashi, Gifu 502, Japan
}

Received June 1, 1992 Accepted October 14, 1992

\begin{abstract}
The ability of IPD-1151T to suppress the induction of human IgE synthesis was investigated with an in vitro model of IgE production mediated by an allergen-specific helper T cell line (SN-4) from a patient allergic to Japanese cedar pollen. IPD-1151T induced a concentration-dependent suppression of purified allergen (Cry $j$ 1)-dependent IgE synthesis in autologous B cell cultures mediated by SN-4, without significantly affecting the IgG synthesis. In addition, the production of interleukin 4 (IL-4) by Cry $j$ 1-activated SN-4 as well as that by phytohemagglutinin (PHA)-stimulated peripheral blood mononuclear cells (PBMC) of normal donors was inhibited in a concentration-dependent manner by the agent. Interestingly, IPD-1151T clearly depressed PHA-induced expression of IL-4 mRNA in normal PBMC, indicating that this agent inhibits IL-4 gene transcription. However, IPD-1151T had no antagonistic action on IL-4, since neither IL-4-induced expression of low-affinity IgE receptor ( $F \mathcal{c} \varepsilon$ RII/CD23) on normal B cells nor soluble Fc $\varepsilon$ RII release from IL-4-stimulated B cells was affected by the agent. On the other hand, IPD-1151T had no effect on the production of interferon- $\gamma$ by both Cry $j$ 1-stimulated SN-4 and anti-CD3 monoclonal antibody-activated $T$ cells of normal donors. These results suggest that the selective suppression of IgE synthesis by IPD-1151T results from the inhibition of IL-4 production by T cells at the gene level.
\end{abstract}

Keywords: IgE production, Interleukin 4 (IL-4), IL-4 mRNA, Interferon- $\gamma$, IPD-1151T (suplatast tosilate)

In the preceding paper (1), ( \pm )-[2-[4-(3-ethoxy-2-hydroxypropoxy) phenylcarbamoyl]ethyl] dimethylsulfonium $p$ toluenesulfonate (IPD-1151T, suplatast tosilate) has been demonstrated to be effective in selectively suppressing the murine $\operatorname{IgE}$ antibody response, possibly by interfering with the production of $T$ cell-derived interleukin 4 (IL-4). Since it has been reported that IL-4 is essentially required for the induction of IgE synthesis both in mice and humans $(2-4)$, additional studies with the human system are needed to evaluate the IgE-suppressive activity of IPD1151T. To this end, we have developed an in vitro model of human IgE synthesis mediated by an allergen-specific and IL-4-producing helper T cell line (TCL), named SN4, from a patient allergic to Japanese cedar pollen (5). Indeed, SN-4 is a helper TCL capable of inducing the synthesis of $\operatorname{IgE}$ and $\operatorname{IgG}$ in both autologous and allogeneic $B$ cells in an HLA-DR-restricted manner upon stimulation with $C r y j$, known to be the purified major allergen (6, 7).

First, the present study was performed to determine the capacity of IPD-1151T to suppress the induction of human IgE synthesis mediated by SN-4, a Cry $j 1$-specific helper TCL. The results obtained indicate that IPD$1151 \mathrm{~T}$ induces the highly selective suppression of $\mathrm{Cry} j \mathrm{j}$ 1dependent $\operatorname{IgE}$ synthesis in autologous B cell cultures mediated by SN-4 through the inhibition of IL-4 production. Next, the mechanisms responsible for the inhibition of IL-4 production by IPD-1151T were preliminarily investigated with activated $T$ cells of normal donors. An important message from the present study is that IPD-1151T inhibits IL-4 gene expression.

\section{MATERIALS AND METHODS}

\section{Materials}

Cry $j 1$ was purified from the crude extract of the Japanese cedar (Cryptomeria japonica) pollen as described elsewhere (6). Phytohemagglutinin (PHA, type P) was purchased from Serva. Human recombinant (r) IL-2, IL-4 and interferon- $\gamma$ (IFN- $\gamma$ ) were obtained from 
Genzyme. Mitomycin C (MMC), cycloheximide, puromycin, 2-aminoethylisothiouronium bromide (AET) and 2mercaptoethanol (2-ME) were purchased from Sigma. Cyclosporin A (CyA) was a kind gift of Sandoz Laboratories. It was dissolved in $50 \%$ ethanol $(5 \mathrm{mg} / \mathrm{ml})$ and diluted by culture medium immediately before use; the final concentration of ethanol was $0.01 \%$. Dulbecco's modified Eagle medium and nonessential amino acids were obtained from Gibco, and agar noble was from Difco Laboratories. Anti-CD3 (OKT3), anti-CD11b (OKM1) and anti-CD21 (OKB7) monoclonal antibodies (mAbs) were purchased from Ortho Laboratories. AntiCD4 (anti-leu-3a), anti-CD8 (anti-leu-2b) and anti-CD14 (anti-leu-M3) mAbs were purchased from Becton Dickinson. Anti-CD20 (anti-B1), anti-CD29 (anti-4B4) and antiCD45RA (anti-2H4) mAbs were obtained from Coulter Immunology. Anti-Fc $\varepsilon$ RII/CD23 mAbs (10/3, 11/4 and $12 / 2$ ) were produced in our laboratory. The production and characterization of these three anti-CD23 $\mathrm{mAbs}$ have been described in detail (8). Human IL-4 cDNA was cloned in our laboratory according to the method of Yokota et al. (9). The cDNA probe specific for human $\beta$ actin was purchased from Wako. These two probes were labeled by random hexanucleotide priming with $\left[{ }^{32} \mathrm{P}\right]-$ dCTP and then heat-denatured. All of the materials used in this study were exactly as described in the preceding paper (1).

\section{Cell preparation}

Human peripheral blood mononuclear cells (PBMC) were isolated from heparinized venous blood by centrifugation on a Ficoll-sodium metrizoate gradient, and $\mathrm{T}$ and $B$ cell fractions were separated from PBMC by rosetting with AET-treated sheep erythrocytes, as previously described $(10,11)$. To obtain purified $T$ cells, rosetting cells were incubated with anti-CD21 and anti-CD11b mAbs and rabbit complement; they contained neither $\mathrm{CD} 20^{+} \mathrm{B}$ cells nor $\mathrm{CD} 14^{+}$monocytes as analyzed by flow cytometry (FACS 440, Becton Dickinson) equipped with argon laser running at $488 \mathrm{~nm}$. To obtain the B cellenriched fractions, non-rosetting cells were treated with anti-CD $3 \mathrm{mAb}$ and rabbit complement; they contained 20 to $30 \% \mathrm{CD}^{4} 4^{+}$monocytes but less than $1 \% \mathrm{CD}^{+} \mathrm{T}$ cells. To obtain further highly purified B cells, the B cellenriched fractions were depleted of monocytes by adherence to plastic dishes and then treated with anti-CD11b $\mathrm{mAb}$ and complement. Highly purified B cell fractions contained more than $90 \% \mathrm{CD}^{2} 0^{+} \mathrm{B}$ cells.

\section{Isolation of allergen-specific helper TCL ( $S N-4)$}

$\mathrm{SN}-4$, a $C r y j$ 1-specific helper TCL, was isolated from PBMC of one patient allergic to Japanese cedar pollen by the use of a soft-agar cloning technique as previously described (5). Briefly, PBMC obtained from the patient were cultured for 5 days with $50 \mu \mathrm{g} / \mathrm{ml}$ of $C r y j 1$ at a density of $1 \times 10^{6}$ cells $/ \mathrm{ml}$ in RPMI 1640 containing $10 \%$ heat-inactivated fetal calf serum (FCS), $1 \%$ nonessential amino acids, $100 \mathrm{U} / \mathrm{ml}$ penicillin, $100 \mu \mathrm{g} / \mathrm{ml}$ streptomycin, $5 \mathrm{mM}$ L-glutamine and $5 \times 10^{-5} \mathrm{M}$ 2-ME (culture medium). Viable cells were harvested, resuspended in Dulbecco's modified Eagle medium, and then cultured in a two-layer soft-agar system in 35-mm plastic dishes; the upper agar layer $(0.85 \mathrm{ml}$ of $0.32 \%$ agarose $)$ was composed of $2 \times 10^{5}$ autologous antigen-presenting cells (APC, B cell-enriched fractions pretreated with $50 \mu \mathrm{g} / \mathrm{ml}$ of MMC) and $10 \% \mathrm{FCS}$; the lower agar layer $(2.5 \mathrm{ml}$ of $0.5 \%$ agar) was composed of $50 \mu \mathrm{g} / \mathrm{ml}$ of $C r y j 1$ and $10 \%$ FCS. After culture for 5 days, the colonies in the upper layer were picked up and then placed in 96-well round-bottomed microplates with $2 \times 10^{5}$ cells $/ \mathrm{ml}$ of fresh autologous APC in a volume of $0.2 \mathrm{ml}$ of culture medium containing $50 \mu \mathrm{g} / \mathrm{ml}$ of $C r y j 1$ and $100 \mathrm{U} / \mathrm{ml}$ of rIL-2. Every 3 days, one-half of the medium was replaced by fresh culture medium containing rIL-2. After sufficient growth, TCLs were harvested, adjusted to $1 \times 10^{5} \mathrm{cells} / \mathrm{ml}$, and then cultured with $50 \mu \mathrm{g} / \mathrm{ml}$ of $C r y j 1,100 \mathrm{U} / \mathrm{ml}$ of rIL-2 and $1 \times 10^{5}$ cells $/ \mathrm{ml}$ of fresh autologous APC in 96-well flatbottomed microplates. Cultures were fed every 3 days, and TCLs were further expanded in culture medium containing rIL-2 with many cycles of stimulation with Cry $j 1$ in the presence of autologous APC. Several TCLs were maintained for 3 to 6 months, and one TCL, named SN4 , was finally selected on the basis of its excellent ability to proliferate in response to only Cry $j 1$. Phenotypic analysis by FACS showed that SN-4 belongs to the helper/ inducer subsets of T cells. Indeed, $\mathrm{SN}-4$ was positive for CD3, CD4 and CD29, but negative for $\mathrm{CD} 8$ and CD45RA. For the functional assay, SN-4 was rested in culture medium containing rIL-2 for 7 days after the last stimulation with $C r y j 1$.

\section{Culture condition for production of $\operatorname{IgE}$ and $\operatorname{IgG}$}

Autologous B cell-enriched fractions $\left(1 \times 10^{5}\right.$ cells/ well) were cultured in the presence of SN-4 $\left(4 \times 10^{4}\right.$ cells/well) with $50 \mu \mathrm{g} / \mathrm{ml}$ of $C r y j 1$ in a total volume of $0.2 \mathrm{ml}$ in round-bottomed, 96-well microplates at $37^{\circ} \mathrm{C}$. To estimate the passive release of preformed IgE and IgG into the culture supernatant, both cycloheximide and puromycin were added to some cultures $(10,11)$. After 10 days, the culture supernatant was pooled from three wells, and IgE and IgG concentrations were measured by a solid-phase sandwich radioimmunoassay (RIA) as previously described $(10,11)$.

\section{Assay for cytokines}

The cultures for cytokine production were set up at 
$37^{\circ} \mathrm{C}$ as follows: the mixtures of $\mathrm{SN}-4$ and autologous APC (each $1 \times 10^{5}$ cells/well) were cultured for 3 days with $50 \mu \mathrm{g} / \mathrm{ml}$ of Cry $j 1$ in a total volume of $0.2 \mathrm{ml}$ in round-bottomed microplates; PBMC $\left(2 \times 10^{5}\right.$ cells/well $)$ from normal donors were cultured for $24 \mathrm{hr}$ with 10 $\mu \mathrm{g} / \mathrm{ml}$ of PHA in a total volume of $0.2 \mathrm{ml}$ in flat-bottomed, 96-well microplates; and purified $\mathrm{T}$ cells $\left(1 \times 10^{5}\right.$ cells/well) from normal donors were cultured in a total volume of $1 \mathrm{ml}$ for $24 \mathrm{hr}$ with anti-CD3 $\mathrm{mAb}$ that had been immobilized on flat-bottomed, 24-well plates at a concentration of $5 \mu \mathrm{g} / \mathrm{ml}$. Cytokines in the culture supernatants were quantitatively assayed by the following commercially available kits: IL-4 (Quantikine human IL-4 ELISA kit, Research and Diagnosis System Inc.) and IFN- $\gamma$ (specific RIA kit, Centcor). The sensitivity of the assay was $30 \mathrm{pg} / \mathrm{ml}$ for IL-4 and $1 \mathrm{U} / \mathrm{ml}$ for IFN- $\gamma$.

\section{Fc $\varepsilon$ RII expression}

Highly purified $B$ cells from normal donors were suspended in culture medium at a density of $1 \times 10^{6}$ cells $/ \mathrm{ml}$, and the cells were cultured in the absence or presence of $100 \mathrm{U} / \mathrm{ml} \mathrm{rIL}-4$ for 3 days at $37^{\circ} \mathrm{C}$. The cells were washed and then incubated with biotinylated-12/2 $\left(1 \mu \mathrm{g} / 10^{5}\right.$ cells $)$ for $90 \mathrm{~min}$ at $4{ }^{\circ} \mathrm{C}$. After washing, the cells were further incubated with phycoerythrin-conjugated streptravidin for $30 \mathrm{~min}$ at $4^{\circ} \mathrm{C}$. They were washed again with cold staining buffer, and $10^{4}$ cells were analyzed by single-color FACS.

\section{Assay for soluble Fc $\varepsilon R I I$}

Highly purified $B$ cells from normal donors were cultured under conditions identical to those described above. Soluble Fc $\varepsilon$ RII in the culture supernatant was quantitatively measured by a sensitive solid-phase sandwich RIA with the use of two different anti-CD23 mAbs, 10/3 and $11 / 4$, that recognize a different epitope of Fc $\varepsilon$ RII, as previously described (8). Briefly, polyvinyl microplate wells were coated with $10 \mu \mathrm{g} / \mathrm{ml}$ of $10 / 3$, and their unbound sites were blocked by incubation with $10 \%$ FCS. After washing, samples were incubated overnight in the wells. The plates were washed, and then ${ }^{125}$ I-labeled $11 / 4$ was added to each well. After incubation for $8 \mathrm{hr}$, the wells were washed thoroughly, and the radioactivity was determined by a gamma counter. The sensitivity of the assay was $12.5 \mathrm{pg} / \mathrm{ml}$ when the purified soluble Fc $\varepsilon$ RII was used as a standard.

\section{Northern blot analysis of IL-4 $m R N A$}

PBMC from normal donors at a density of $1 \times 10^{6}$ cells $/ \mathrm{ml}$ were stimulated with $10 \mu \mathrm{g} / \mathrm{ml}$ of PHA in a total volume of $1 \mathrm{ml}$ in flat-bottomed, 24-well plates. After culture for $6 \mathrm{hr}$, total RNA was extracted from the cells by the single step method (12). Twenty micrograms of total RNA was electrophoresed in $1 \%$ agarose gel containing $6 \%$ formaldehyde, and then transferred to nylon membranes. Membranes were hybridized with a ${ }^{32} \mathrm{P}$-labeled cDNA probe of human IL-4 for $24 \mathrm{hr}$ at $45^{\circ} \mathrm{C}$. Northern blot analysis for the human $\beta$-actin control were also performed on membranes transferred from gels prepared in parallel from the same RNA samples. Membranes were washed, air-dried, and then exposed to Kodak XAR-5 films with intensifier screens for 5 days at $-70^{\circ} \mathrm{C}$. Densitometric analysis was carried out with a video densitometer (BioRad model 620).

\section{RESULTS}

\section{Effect on IgE synthesis mediated by $S N-4$}

SN-4 has been demonstrated to be a Cry $j$ 1-specific and HLA-DR-restricted helper TCL capable of inducing the synthesis of both IgE and IgG in autologous B cells as well as in HLA-DRw9-matched allogeneic B cells of normal donors (5). Here, autologous B cell-enriched fractions containing monocytes were cultured in the absence or presence of IPD-1151T with SN-4 and Cryj 1 for 10 days, and the IgE-suppressive activity of the agent was evaluated in this culture system. Table 1 shows the results obtained in two different experiments. The induction of Cry $j$ 1-dependent IgE synthesis mediated by $\mathrm{SN}-4$ was

Table 1. Effect of IPD-1151T on IgE and IgG synthesis by autologous B cells cultured with SN-4 and Cry $j 1$

\begin{tabular}{|c|c|c|c|c|c|}
\hline \multirow{2}{*}{ Group } & \multirow{2}{*}{$\begin{array}{l}\text { Concentration } \\
(\mu \mathrm{g} / \mathrm{ml})\end{array}$} & \multicolumn{2}{|c|}{ Exp. 1} & \multicolumn{2}{|c|}{ Exp. 2} \\
\hline & & $\operatorname{IgE}(\mathrm{ng} / \mathrm{ml})$ & $\operatorname{IgG}(\mu \mathrm{g} / \mathrm{ml})$ & $\operatorname{IgE}(\mathrm{ng} / \mathrm{ml})$ & $\operatorname{IgG}(\mu \mathrm{g} / \mathrm{ml})$ \\
\hline Control & & 6.6 & 2.7 & 17.6 & 3.7 \\
\hline \multirow[t]{2}{*}{ IPD-1151T } & 1 & 5.3 & 2.6 & 7.8 & 3.5 \\
\hline & 10 & 2.9 & 2.5 & 5.0 & 3.3 \\
\hline
\end{tabular}

Autologous B cell-enriched fractions were cultured in the absence or presence of IPD$1151 \mathrm{~T}$ for 10 days with SN-4 and Cry $j 1$. Each value indicates the mean of duplicate assays. The mean coefficient of value was less than $10 \%$. 


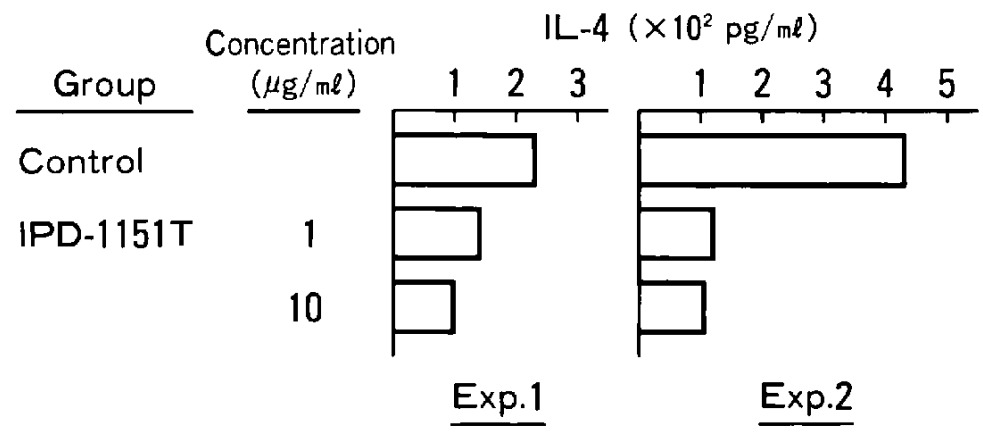

Fig. 1. Effect of IPD-1151T on IL-4 production by SN-4. The mixtures of SN-4 and autologous APC were cultured in the absence or presence of IPD-1151T with Cry $j 1$ for 3 days. Each value indicates the mean of duplicate assays. The mean coefficient of value was less than $10 \%$.

suppressed in a concentration-dependent manner by IPD$1151 \mathrm{~T}(1$ and $10 \mu \mathrm{g} / \mathrm{ml}$ ). In contrast, this agent had only a minimal effect on the IgG response. Indeed, $10 \mu \mathrm{g} / \mathrm{ml}$ of IPD-1151T, although capable of inducing $56-72 \%$ suppression of the IgE synthesis, induced no more than approximately $10 \%$ suppression of the IgG synthesis. These results indicate that the suppression of human Ig synthesis by IPD-1151T is highly specific for the IgE isotype.

\section{Effect on IL-4 production}

Since the induction of IgE synthesis mediated by SN-4 has been shown to be absolutely dependent upon the production of endogeneous IL-4 (5), we first studied whether IPD-1151T inhibits IL-4 production by SN-4. Upon stimulation of SN-4 with Cry $j 1$ in the presence of autologous APC for 3 days, high levels of IL- 4 were detected in the culture supernatants. As illustrated in Fig. 1, IL-4 production was inhibited in a concentration-dependent manner by IPD-1151T ( 1 and $10 \mu \mathrm{g} / \mathrm{ml}$ ), indicating that this agent is effective in inhibiting the production of IL-4 by SN-4. Next, the ability of IPD-1151T to inhibit IL-4 production was investigated in normal lymphocytes. To this end, PBMC from normal donors were stimulated in the absence or presence of IPD-1151T for $24 \mathrm{hr}$ with

Table 2. Effect of IPD-1151T on IL-4 production by PBMC stimulated with PHA

\begin{tabular}{lcc}
\hline Group & $\begin{array}{c}\text { Concentration } \\
(\mu \mathrm{g} / \mathrm{ml})\end{array}$ & $\begin{array}{c}\mathrm{IL}-4 \\
(\mathrm{pg} / \mathrm{ml})\end{array}$ \\
\hline Control & & $417 \pm 75$ \\
IPD-1151T & 1 & $324 \pm 54^{*}$ \\
& 10 & $258 \pm 38^{*}$ \\
\hline
\end{tabular}

PBMC from normal individuals were cultured in the absence or presence of IPD-1151T with PHA for $24 \mathrm{hr}$. The data represent the mean \pm S.E. of results obtained in five donors. ${ }^{*}$ : Statistically significant difference from the control at $\mathbf{P}<0.05$ (paired $t$-test).
PHA, one of the potent T cell mitogens. Table 2 summarizes the results obtained in five different donors. IPD$1151 \mathrm{~T}$ at concentrations of 1 and $10 \mu \mathrm{g} / \mathrm{ml}$ significantly inhibited IL-4 production by PHA-stimulated PBMC in a concentration-dependent fashion. To further study the mode of action of IPD-1151T upon IL-4 production at the gene level, IL- 4 mRNA expression was examined by Northern blot analysis. In this experiment, normal PBMC were stimulated in the absence or presence of IPD-1151T or CyA with PHA for $6 \mathrm{hr}$, and three independent experiments were performed for each Northern blot analysis. A representative result is shown in Fig. 2. IPD$1151 \mathrm{~T}(10 \mu \mathrm{g} / \mathrm{ml})$ clearly reduced the level of IL-4 mRNA with a size of $0.63 \mathrm{~kb}$ in PHA-stimulated PBMC. The level of $\beta$-actin mRNA with a size of $1.9 \mathrm{~kb}$, however, was not affected by IPD-1151T. Approximately $30 \%$ decrease in the relative density of IL-4 transcripts was observed in the culture with $10 \mu \mathrm{g} / \mathrm{ml}$ of IPD-1151T, as determined by standardizing with the density of $\beta$-actin mRNA ( 1.0 in the control versus $0.7 \pm 0.1$ in the culture with the agent, mean \pm S.E. of three experiments). These results indicate that IPD-1151T inhibits the activation of the IL-4 gene without affecting the level of $\beta$-actin mRNA. Almost complete inhibition of IL-4 mRNA expression was obtained with CyA $(1 \mu \mathrm{g} / \mathrm{ml})$, which is known to inhibit the induction of cytokine gene transcription (13).

\section{Effect on IFN- $\gamma$ production}

$\mathrm{SN}-4$ has been shown to produce not only high levels of IL-4 but also very small amounts of IFN- $\gamma(5)$. Our preliminary approach was to first investigate the effect of IPD$1151 \mathrm{~T}$ on IFN- $\gamma$ production by SN-4. In this experiment, the same culture supernatants obtained in two experiments in which the ability of IPD-1151T to inhibit IL-4 production by $\mathrm{SN}-4$ had been examined were used for the determination of IFN- $\gamma$ levels. One of these two culture supernatants contained detectable amounts of IFN- $\gamma$, 


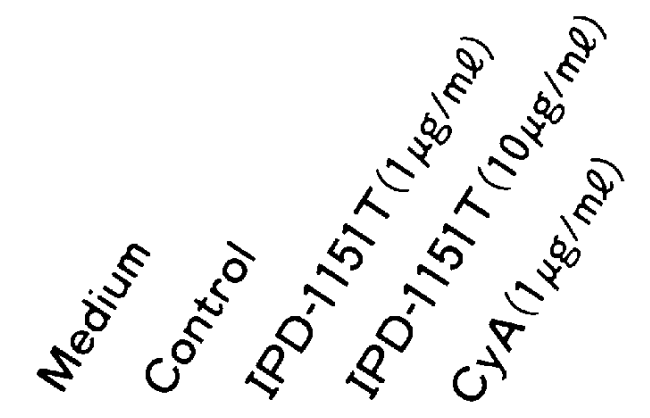

\section{$28 \mathrm{~S} \rightarrow$}

$18 S \rightarrow$

\section{IL-4 mRNA $(0.63 \mathrm{~kb})$}

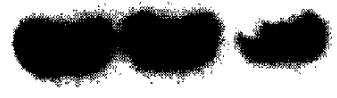

\section{Actin mRNA $(1.9 \mathrm{~kb})$ \\ Relative density $<0.1 \quad 1.0 \quad 1.0 \quad 0.8<0.1$}

Fig. 2. Effect of IPD-1151T and CyA on IL-4 mRNA expression in PHA-stimulated cells. Normal PBMC were cultured in the absence or presence of IPD-1151T or CyA with PHA for $6 \mathrm{hr}$. The level of IL- 4 or $\beta$-actin mRNA was determined by Northern blot analysis, and the relative density of IL-4 mRNA was calculated by standardizing with the density of $\beta$-actin mRNA. The relative density of $\mathrm{IL}-4$ mRNA in the control is expressed as 1.0 .

whereas the other did not. Even though only one experiment was performed, IPD-1151T did not affect the production of IFN- $\gamma$ by SN-4: $3.8 \mathrm{U} / \mathrm{ml}$ in the control versus 3.8 and $4.0 \mathrm{U} / \mathrm{ml}$ in the cultures with 1 and $10 \mu \mathrm{g} / \mathrm{ml}$ of the agent, respectively. However, it must be noted that the sensitivity of the IFN- $\gamma$ assay is no more than $1 \mathrm{U} / \mathrm{ml}$. Therefore, the effect of IPD-1151T on IFN- $\gamma$ production was further investigated in a culture system capable of producing the high levels of IFN- $y$. To this end, purified $T$ cells from normal donors were cultured in the absence or presence of IPD-11151T or CyA for $24 \mathrm{hr}$ with anti$\mathrm{CD} 3 \mathrm{mAb}$ that had been immobilized on the bottoms of the plastic wells. Indeed, normal $\mathrm{T}$ cells produced large amounts of IFN- $\gamma$ in response to anti-CD $3 \mathrm{mAb}$. Table 3 summarizes the results obtained in five different donors. IPD-1151T at concentrations of 1 and $10 \mu \mathrm{g} / \mathrm{ml}$ had no 
effect on the production of IFN- $\gamma$ by $\mathrm{T}$ cells stimulated with anti-CD $3 \mathrm{mAb}$. In contrast, CyA $(1 \mu \mathrm{g} / \mathrm{ml})$, a potent

Table 3. Effect of IPD-1151T and CyA on IFN- $\gamma$ production by $\mathrm{T}$ cells stimulated with anti-CD3 mAb

\begin{tabular}{lcc}
\hline Group & $\begin{array}{c}\text { Concentration } \\
(\mu \mathrm{g} / \mathrm{ml})\end{array}$ & IFN- $\gamma(\mathrm{U} / \mathrm{ml})$ \\
\hline Control & & $97.6 \pm 6.5$ \\
IPD-1151T & 1 & $96.4 \pm 10.7$ \\
& 10 & $96.0 \pm 10.8$ \\
CyA & 1 & $24.4 \pm 2.9^{*}$ \\
\hline
\end{tabular}

Purified $\mathrm{T}$ cells from normal donors were cultured in the absence or presence of IPD-1151T or CyA for $24 \mathrm{hr}$ with immobilized anti-CD3 $\mathrm{mAb}$. The data represent the mean \pm S.E. of results obtained in five donors. *: Statistically significant difference from the control at $\mathbf{P}<0.01$ (paired $t$-test). inhibitor of cytokine production, induced the marked inhibition of IFN- $\gamma$ production.

\section{Effect on $r I L-4-i n d u c e d ~ F c \varepsilon R I I$ expression and soluble} $F c \& R I I$ release

Highly purified B cells from normal donors were stimulated in the absence or presence of IPD-1151T or IFN- $\gamma$ with rIL- 4 for 3 days, and then analyzed for the expression of Fc $\varepsilon$ RII by means of single-color FACS. As shown in Fig. 3, IFN- $\gamma(1,000 \mathrm{U} / \mathrm{ml})$ but not IPD-1151T ( 1 and $10 \mu \mathrm{g} / \mathrm{ml}$ ) inhibited rIL-4-induced expression of Fc $\varepsilon$ RII on B cells. The levels of soluble Fc $\varepsilon$ RII in the culture supernatants were also measured by a sensitive solidphase RIA. As summarized in Fig. 4, soluble Fc $\varepsilon$ RII release was not affected by IPD-1151T at any concentration, while it was strongly inhibited by the addition of IFN- $\gamma$. These results indicate that in contrast to IFN- $\gamma$, IPD-1151T has no antagonistic action on IL-4.

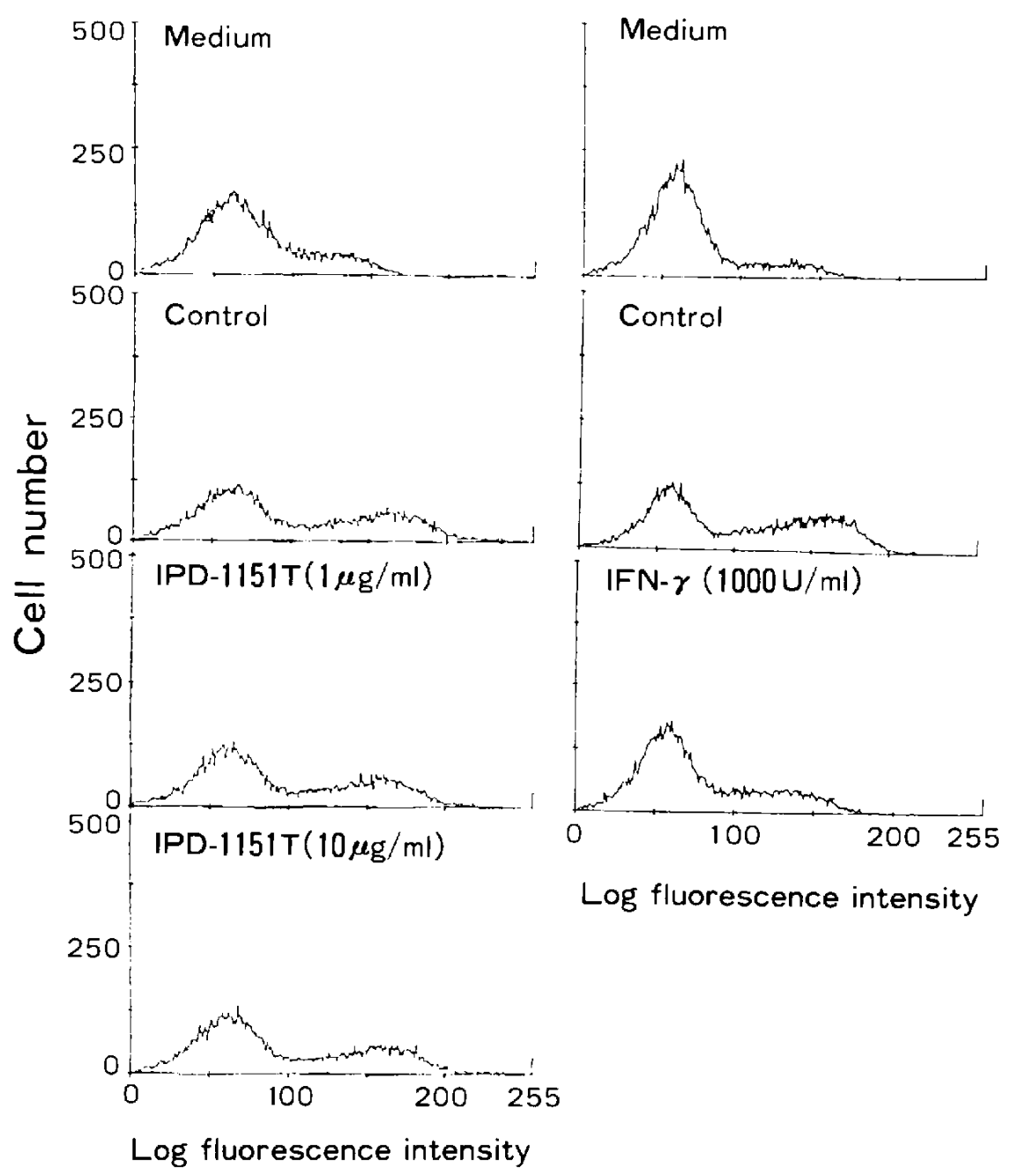

Fig. 3. Effect of IPD-1151T and IFN- $\gamma$ on rIL-4-induced Fc $\varepsilon$ RII expression on B cells. Normal B cells were cultured in the absence or presence of IPD-1151T or IFN- $\gamma$ with rIL-4 for 3 days. The Fc $\varepsilon$ RII expression was analyzed by single-color FACS. 


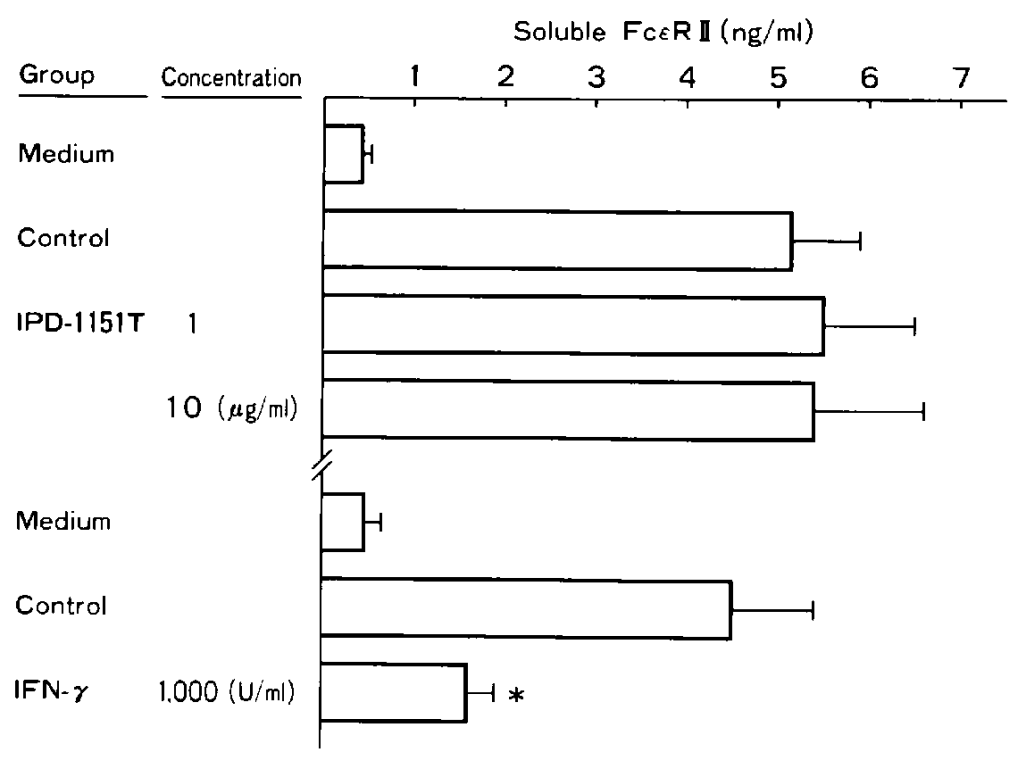

Fig. 4. Effect of IPD-1151T and IFN- $\gamma$ on soluble Fc $\varepsilon$ RII release from rIL-4-stimulated B cells. Normal B cells were cultured in the absence or presence of IPD-1151T or IFN- $\gamma$ with IL-4 for 3 days. Soluble Fc $\varepsilon$ RII was measured by a solid-phase sandwich RIA with the use of two different anti-CD23 mAbs. The results are expressed as the mean \pm S.E. of three or four donors. *: Statistically significant difference from the control at $\mathrm{P}<0.05$ (paired $t$-test).

\section{DISCUSSION}

In the present study, the IgE-suppressive activity of IPD-1151T was evaluated by establishing an in vitro model of human IgE production. To this end, we have generated SN-4, a Cry $j$ 1-specific and HLA-DR-restricted $\mathrm{CD} 4^{+} \mathrm{TCL}$, from a patient allergic to Japanese cedar pollen (5). Upon stimulation with $C r y j 1, \mathrm{SN}-4$ was able to induce the synthesis of both $\operatorname{IgE}$ and $\operatorname{IgG}$ in autologous $B$ cell cultures. The induction of IgE synthesis mediated by SN-4 was suppressed in a concentration-dependent fashion by the addition of IPD-1151T to the cultures. The same treatment, however, had only a minimal effect on the IgG response, thus indicating that the suppression of human Ig synthesis by IPD-1151T is highly specific for the IgE isotype. This is consistent with the previous finding (1) that IPD-1151T exerted a selective influence on the IgE antibody response in the mouse system.

Our previous analysis of SN-4 (5) has demonstrated that its IgE-inducing activity is related to the production of IL-4 required to activate B cells to synthesize IgE. More recent studies by several investigators $(14-16)$ have clearly indicated that whereas human $\mathrm{CD}^{+} \mathrm{T}$ cell clones have different profiles of cytokine production, they are comparable to those of mouse Th1 and Th2 subsets classified by Coffman and his group (17). For example, allergen-specific $\mathrm{CD}^{+} \mathrm{T}$ cell clones from allergic patients induce the production of high levels of IL-4 but little or no production of IFN- $\gamma$, indicating that they fit the Th2 pat- tern. Indeed, SN-4 with aberrant ratios of IL-4 versus IFN- $\gamma$ production is most likely to be the equivalent of mouse Th 2 cells. Interestingly, IL-4 production by SN-4 was inhibited in a concentration-dependent fashion by IPD-1151T, whereas IFN- $\gamma$ production was not affected. The great efficacy of IPD-1151T in inhibiting IL-4 production thus reflects its IgE-suppressive activity, since the induction of IgE synthesis mediated by SN-4 was shown to be strongly suppressed by adding anti-IL-4 antibody in culture (5). This finding is in keeping with the previous report (1) that IPD-1151T exerted an inhibitory effect on murine IL- 4 production by a Th 2 clone. The observation that IPD-1151T significantly inhibited IL-4 production by PHA-stimulated PBMC of normal donors further confirms that this agent is indeed effective in inhibiting IL-4 production by human T cells. PHA is known to induce the production of some cytokines, due to the activation of transcription of cytokine genes $(18,19)$. To explore the mode of action of IPD-1151T in the inhibition of IL-4 production, Northern blot analysis was performed in PHA-stimulated cells but not in $\mathrm{SN}-4$ because it was difficult to obtain a supply of the patient's cells. We found that IPD-1151T clearly reduced the level of IL-4 mRNA in PHA-stimulated PBMC of normal donors, indicating that the agent inhibits some stages of the cascade of events leading to IL-4 production at the gene level. Since IL-4 has been shown to have the site of processing of the signal sequence (9), the inhibitory activity of IPD$1151 \mathrm{~T}$ on several proteases was also investigated. 
However, this agent had no inhibitory effect on the activities of proteases such as trypsin, chymotrypsin and papain (data not shown). These results strongly suggest that IPD-1151T acts directly at the transcriptional level of the IL-4 gene, but not at the processing level of IL-4 secretion.

Cytokine production involved in $\mathrm{T}$ cell activation has been demonstrated to be regulated by some immunosuppressive drugs such as CyA and FK506 (13, 20-22). For example, both drugs are known to interact with peptidylprolyl cis-trans isomerase and to inhibit cytokine production at the gene level. Indeed, CyA was effective in inhibiting IL-4 mRNA expression in PHA-stimulated PBMC of normal donors. Moreover, IFN- $\gamma$ production by normal $\mathrm{T}$ cells activated with immobilized anti-CD3 mAb was also inhibited by CyA. These findings indicate that the inhibition of cytokine production by CyA is not limited to IL-4 or IFN- $\gamma$, as already confirmed by several investigators $(13,20,21)$. In contrast, IPD-1151T had no effect on IFN- $\gamma$ production by activated $\mathrm{T}$ cells. These results support the idea that the regulation of cytokine production by IPD-1151T is strikingly different from that by CyA. This idea further suggests that whereas CyA acts on both IFN- $\gamma$-producing Th1 and IL-4-producing Th2 cells, IPD-1151T acts selectively on Th2 cells. However, it must be emphasized that IPD-1151T has no antagonistic action on IL-4, since neither rIL-4-induced Fc $\varepsilon$ RII expression on B cells nor soluble Fc $\varepsilon$ RII release by rIL-4-stimulated cultures was affected by the agent. Therefore, it is most likely that Th2 cells responsible for IL-4 production are targets for the action of IPD-1151T. So far as is known at present, IPD-1151T may be the first drug that inhibits IL4 but not IFN- $\gamma$ production. Interestingly, IPD-1151T is also demonstrated to inhibit not only IL- 5 release from IL-2-activated $T$ cells of patients with nonallergic hyperimmunoglobulinemia $E$ who suffer from Kimura's disease (H. Enokihara, personal communication), but also IL-6 release from PHA-stimulated PBMC of normal donors (Y. Yanagihara, unpublished data). These observations in part confirm that IPD-1151T acts on Th2 cells but not on Th1 cells.

In conclusion, the present study, together with the preceding paper (1), indicates that the IgE-suppressive activity of IPD-1151T is essentially based on the inhibition of IL-4 production by Th2 cells. However, it is unclear why IPD-1151T acts selectively on Th2 subsets. Further studies are required to elucidate the molecular mechanisms responsible for the inhibition of IL-4 production by IPD-1151T.

\section{Acknowledgments}

We thank Dr. H. Yasueda for generously providing the $C r y j$; Dr. T. Koshio, for valuable advice of Northern blot analysis; and Mr. K. Kajiwara, for excellent technical assistance.

\section{REFERENCES}

1 Yanagihara, Y., Kiniwa, M., Ikizawa, K., Yamaya, H., Shida, T., Matsuura, N. and Koda, A.: Suppression of IgE production by IPD-1151T (suplatast tosilate), a new dimethylsulfonium agent: (1) Regulation of murine IgE response. Japan. J. Pharmacol. 61, 23-30 (1993)

2 Coffman, R.L., Ohara, J., Bond, M.W., Carty, J., Zlotnick, A. and Paul, W.E.: B cell stimulatory factor- 1 enhances the $\operatorname{IgE}$ response of lipopolysaccharide-activated B cells. J. Immunol. 136, 4538-4541 (1986)

3 Del Prete, G., Maggi, E., Parronchi, P., Chetien, I., Tiri, A., Macchia, D., Ricci, M., Banchereau, J., De Vries J.E. and Romagnani, S.: IL-4 is an essential factor in the IgE synthesis induced in vitro by human $\mathbf{T}$ cell clones and their supernatants. $\mathrm{J}$. Immunol. 140, 4193-4198 (1988)

4 Pene, J., Rousset, F., Briere, F., Chretien, I., Bonnefoy, J.Y., Spits, H., Yokota, T., Arai, N., Arai, K., Banchereau, J. and de Vries, J.E.: IgE production by normal human lymphocytes is induced by interleukin 4 and suppressed by interferon $\gamma$ and $\alpha$ and prostaglandin $E_{2}$. Proc. Natl. Acad. Sci. U.S.A. 85, 6880-6884 (1988)

5 Yanagihara, Y. and Kiniwa, M.: Analysis of the mechanism of IgE production induced by a helper $T$ cell line specific for the major allergen of Japanese cedar pollen. Clin. Immunol. 22, 694-702 (1990)

6 Yasueda, H., Yui, Y., Shimizu, T. and Shida, T.: Isolation and partial characterization of the major allergen from Japanese cedar (Cryptomeria japonica) pollen. J. Allergy Clin. Immunol. $71,77-86$ (1983)

7 Marsh, D.G., Goodfriend, L., King, T.P., Lowenstein, H. and Platts-Mills, T.A.A.: Allergen nomenclature. Allergy 43, $161-168$ (1988)

8 Yanagihara, Y., Kiniwa, M., Kajiwara, K. and Shida, T.: Establishment of a sensitive radioimmunoassay for the detection of human IgE-binding factor (soluble CD23). Int. Arch. Allergy Immunol. 98, 189- 199 (1992)

9 Yokota, T., Otsuka, T., Mosmann, T., Banchereau, J., De France, T., Blanchard, D., De Vries, J.E., Lee, F. and Arai, K.: Isolation and characterization of a human interleukin cDNA clone, homologous to mouse B-cell stimulatory factor 1 , that expresses B-cell- and T-cell-stimulating activities. Proc. Natl. Acad. Sci. U.S.A. 83, 5894-5898 (1986)

10 Yanagihara, Y., Kajiwara, K., Kiniwa, M., Kamisaki, T., Yui, Y., Shida, T. and Delespesse, G.: Modulation of IgE synthesis by IgE-binding factors released by $\mathrm{T}$ cells of asthmatic patients with elevated serum IgE. Microbiol. Immunol. 31, 261-274 (1987)

11 Yanagihara, Y., Kajiwara, K., Kiniwa, M., Yui, Y., Shida, T. and Delespesse, G.: Enhancement of IgE synthesis and histamine release by $\mathrm{T}$ cell factors derived from atopic patients with bronchial asthma. J. Allergy Clin. Immunol. 79, 448-456 (1987)

12 Chomczynski, P. and Sacchi, N.: Single-step method of RNA isolation by acid guanidinium thiocyanate-phenol-chloroform 
extraction. Anal. Biochem. 162, 156-159 (1987)

13 Granelli-Piperno, A., Inaba, K. and Steinman, R.: Stimulation of lymphokine release from $\mathrm{T}$ lymphoblasts. Requirement for mRNA synthesis and inhibition by cyclosporin A. J. Exp. Med. 160, 1792-1802 (1984)

14 Wierenga, E.A., Snoek, M., Jansen, H.M., Bos, J.D. and van Lier, R.A.W.: Human atopen-specific types 1 and 2 T helper cell clones. J. Immunol. 174, 2942-2949 (1991)

15 Del Plete, G., De Carli, M., Mastromauro, C., Macchia, D., Biagiotti, R.O., Ricci, M. and Romagnani, S.: Purified protein derivative of Mycobacterium tuberculosis and excretory-secretory antigen(s) of Toxocara canis expand in vitro human $T$ cells with stable and opposite (type $1 \mathrm{~T}$ helper or type $2 \mathrm{~T}$ helper) profile of cytokine production. J. Clin. Invest. 88, 346-350 (1991)

16 Maggi, E., Parronchi, P., Manetti, R., Simonelli, C., Piccinni, M.P., Rugiu, F.S., De Carli, M., Ricci, M. and Romagnani, S.: Reciprocal regulatory effects of IFN- $\gamma$ and IL-4 on the in vitro development of human Th1 and Th2 clones. J. Immunol. 148, 2142-2147 (1992)

17 Mosmann, T.R., Cherwinski, H., Bond, M.W., Gielden, M.A. and Coffman, R.L.: Two types of murine helper T cell clone. I.
Definition according to profiles of lymphokine activities and secreted proteins. J. Immunol. 136, 2348-2357 (1986)

18 Kern, J.K., Reed, J.C., Daniele, R.P. and Nowell, P.C.: The role of the accessory cell in mitogen-stimulated human $T$ cell gene expression. J. Immunol. 137, 764-769 (1986)

19 Horii, Y., Muraguchi, A., Suematsu, S., Matsuda, T., Yoshizaki, K., Hirano, T. and Kishimoto, T.: Regulation of BSF-2/IL-6 production by mononuclear cells: Macrophagedependent synthesis of BSF-2/IL-6 production by T cells. J. Immunol. 141, 1529-1535 (1988)

20 Tocci, M.J., Matkovich, D.A., Collier, K.A., Kwok, P., Dumont, F., Lin, S., Degudicibus, S., Siekierka, J.J., Chin, J. and Hutchinson, N.I.: The immunosuppressant FK506 selectively inhibits expression of early $\mathrm{T}$ cell activation genes. J. Immunol. 143, 718-726 (1989)

21 Takahashi, N., Hayano, T. and Suzuki, M.: Peptidyl-proryl cis-trans isomerase is the cyclosporin A-binding protein cyclophilin. Nature 337, 473-475 (1989)

22 Siekierka, J., Hung, S., Poe, M., Lin, C. and Signal, N.: A cytosolic binding protein for the immunosuppressant FK506 has peptidyl-prolyl isomerase activity but is distinct from cyclophilin. Nature 341, 755-757 (1989) 